\title{
PENGARUH KONSUMSI MINUMAN MADU TERHADAP KADAR GLUKOSA DARAH ATLET SEPAK BOLA REMAJA SELAMA SIMULASI PERTANDINGAN
}

\author{
Agustya Dewi Anggraini, Etisa Adi Murbawani \\ Program Studi Ilmu Gizi Fakultas Kedokteran Universitas Diponegoro \\ Jl.Dr.Sutomo No.18, Semarang, Telp (024) 8453708, Email : gizifk@undip.ac.id
}

\begin{abstract}
Background: Blood glucose availability during exercise or match is one of the factors affecting endurance performance. Simple carbohydrate beverage ingestion during exercise or match can help improve athlete's performance by maintaining blood glucose levels and delay fatigue. Honey is a natural source of carbohydrate that can provide energy during endurance exercise.

Objective: The purpose of this study was to determine the effects of ingesting honey-based beverage on blood glucose levels of adolescent soccer players during match simulation.

Method: Eighteen male soccer players between the ages of 16-18 in Persatuan Sepak Bola Kudus (PERSIKU) participated in this crossover study. The subjects were given honey beverage and plain water (placebo) during two occasions of soccer match simulation. Both honey beverage and plain water were given 200 ml every 20 minutes during 100 minutes of soccer match simulation. Blood glucose levels were measured immediately before and after the match simulation.

Result: There was no significant difference in blood glucose levels before and after the match simulation on honey beverage treatment. Significant difference was found in plain water (placebo) trial. Blood glucose level was decreased $1.89 \pm 34.17 \mathrm{mg} / \mathrm{dl}$ on honey beverage treatment, and decreased $11.22 \pm 0.013 \mathrm{mg} / \mathrm{dl}$ during match simulation on plain water (placebo) trial.

Conclusion: Ingesting honey beverage during match simulation is more effective in maintaining blood glucose levels compared to plain water (placebo).
\end{abstract}

Keywords: honey, carbohydrate beverage, blood glucose levels, soccer athletes

\begin{abstract}
ABSTRAK
Latar Belakang: Ketersediaan glukosa darah selama latihan atau pertandingan merupakan salah satu faktor yang berpengaruh terhadap performa endurance. Pemberian minuman yang mengandung karbohidrat sederhana selama latihan atau pertandingan dapat membantu meningkatkan performa atlet dengan mempertahankan kadar glukosa darah dan menunda kelelahan. Madu merupakan sumber karbohidrat alami yang dapat bertindak sebagai penyuplai energi pada olahraga endurance.

Tujuan: Penelitian ini bertujuan untuk mengetahui pengaruh konsumsi minuman madu terhadap kadar glukosa darah atlet sepak bola remaja selama simulasi pertandingan.

Metode: Penelitian ini merupakan penelitian eksperimental dengan rancangan Crossover study. 18 atlet sepak bola usia 16-18 tahun di Persatuan Sepak Bola Kudus (PERSIKU) berpartisipasi dalam penelitian dan menjalani dua kali simulasi pertandingan. Subjek menerima intervensi pemberian minuman madu dan air putih (plasebo) sebanyak $200 \mathrm{ml}$ setiap interval 20 menit selama 100 menit simulasi pertandingan. Kadar glukosa darah diukur sesaat sebelum dan setelah simulasi pertandingan.

Hasil: Terdapat penurunan yang tidak bermakna sebesar $1.89 \pm 34.17 \mathrm{mg} /$ dl antara kadar glukosa darah sebelum dan setelah simulasi pertandingan pada perlakuan minuman madu $(p=0.817)$. Terdapat penurunan yang bermakna sebesar $11.22 \pm 0.013 \mathrm{mg} / \mathrm{dl}$ antara kadar glukosa darah sebelum dan setelah simulasi pertandingan pada perlakuan air putih $(p=0.013)$.
\end{abstract}

Simpulan: Pemberian minuman madu lebih efektif dalam mempertahankan kadar glukosa darah selama simulasi pertandingan dibanding air putih (plasebo).

Kata kunci: madu, minuman berkarbohidrat, kadar glukosa darah, atlet sepak bola

\section{PENDAHULUAN}

Sepak bola merupakan olahraga endurance berintensitas tinggi yang berlangsung selama lebih dari 90 menit. $^{1,2}$ Selama pertandingan, atlet melakukan aktivitas yang bersifat intermiten seperti berjalan, sprint, berlari, dribble, menendang, serta meloncat. ${ }^{1,2}$ Rata-rata dalam setiap pertandingan, atlet dapat berlari menempuh jarak 10-12 km dan mengeluarkan energi sebanyak 800-1500 kalori. ${ }^{2}$

Salah satu faktor yang berpengaruh terhadap performa endurance dalam sepak bola adalah ketersediaan glukosa darah selama latihan atau pertandingan. ${ }^{3,4}$ Pada olahraga berdurasi lama, 
apabila pemenuhan karbohidrat eksogen tidak diperoleh dari konsumsi oral, maka laju pemecahan glukosa yang berasal dari glikogen hati tidak akan cukup untuk mengkompensasi pemakaian glukosa oleh otot dan jaringan lain.,4 Sementara itu, glikogen otot menurun selama pertandingan sepak bola, bahkan sebanyak $7 \%$ serat otot hampir kehilangan semua cadangan glikogennya setelah pertandingan. ${ }^{5}$ Dalam kondisi ini, hipoglikemia dapat terjadi, di mana kadar glukosa darah turun hingga $3 \mathrm{mmol} / \mathrm{liter}$ (setara dengan $54 \mathrm{mg} / \mathrm{dl}){ }^{4} \quad$ Berkurangnya simpanan karbohidrat dalam tubuh serta konsumsi cairan yang tidak mencukupi hingga mengakibatkan dehidrasi merupakan penyebab terjadinya penurunan performa olahraga. ${ }^{6-8}$

Salah satu cara yang dapat digunakan untuk menyuplai energi pada atlet selama latihan maupun pertandingan yakni dengan pemberian minuman yang mengandung karbohidrat. ${ }^{3,49}$ Pemberian minuman dengan kandungan karbohidrat sederhana 6-8\% selama latihan atau pertandingan dapat membantu meningkatkan performa atlet dengan menunda kelelahan. ${ }^{3,49-15}$ Pada atlet yang berlatih selama lebih dari satu jam, penambahan karbohidrat sederhana sebanyak 30-60 gram per jam dalam minuman diperlukan untuk membantu tubuh dalam mempertahankan kadar glukosa darah dan glikogen otot sehingga ketersediaan energi tetap terjaga, serta terjadinya kelelahan dapat ditunda. ${ }^{7,8,16,17}$

Madu merupakan produk pemanis alami yang banyak memberikan manfaat kesehatan, serta dapat menjadi sumber energi yang baik bagi atlet. ${ }^{18}$ Komponen gizi utama dalam madu adalah karbohidrat dengan unsur monosakarida glukosa dan fruktosa. ${ }^{18,19}$ Kadar karbohidrat pada madu yang tinggi telah memberikan bukti klinis bahwa madu dapat bertindak sebagai penyuplai energi pada olahraga endurance. ${ }^{20}$ Berdasarkan hasil pengujian kandungan zat gizi larutan madu (rasio 1:12.5) di laboratorium pengujian mutu dan keamanan pangan Fakultas Teknologi Pertanian Universitas Brawijaya Malang, diperoleh hasil bahwa kadar karbohidrat dalam larutan madu tersebut sebesar $7.94 \%$. Nilai ini masih dalam batas optimal kadar karbohidrat untuk minuman selama olahraga yakni $6-8 \%$. Minuman dengan kandungan karbohidrat $>10 \%$ perlu dihindari karena dapat memperlambat proses absorpsi cairan di dalam tubuh dan menimbulkan gangguan pencernaan, sehingga menghambat rehidrasi dan mengganggu peforma atlet. $^{3}$
Telah banyak penelitian yang menguji pengaruh pemberian minuman berkarbohidrat sederhana terhadap performa atlet. Beberapa penelitian tersebut menggunakan jenis minuman berkarbohidrat komersial. Penelitian yang melibatkan madu sebagai alternatif sumber karbohidrat alami selama latihan pada olahraga sepak bola belum banyak dilakukan. Penelitian ini dilaksanakan di Persatuan Sepak Bola Kudus (PERSIKU) U-18. Klub ini merupakan klub binaan atlet sepak bola usia remaja (16-18 tahun) yang memiliki jadwal latihan rutin guna meningkatkan performa para atlet agar berprestasi dalam setiap kompetisi. Beberapa prestasi yang pernah dicapai PERSIKU U-18 antara lain juara 1 Piala Suratin tingkat provinsi Jawa Tengah pada tahun 2011, juara 1 turnamen Segi Empat di Kudus, serta juara 2 turnamen Segi Empat di Semarang pada tahun 2012.

Penelitian pada atlet PERSIKU U-18 pernah dilakukan pada Agustus 2012 dengan menguji pengaruh pemberian air kelapa sebagai cairan rehidrasi selama latihan terhadap kebugaran atlet sepak bola. Hasil yang diperoleh menunjukkan bahwa terdapat peningkatan nilai $\mathrm{VO}_{2}$ maks yang signifikan pada kelompok atlet yang diberikan air kelapa selama latihan. Dengan menggunakan cairan rehidrasi yang berbeda, penelitian ini bertujuan untuk mengetahui pengaruh konsumsi minuman madu terhadap kadar glukosa darah pada atlet sepak bola remaja selama simulasi pertandingan.

\section{METODE}

Penelitian ini dilaksanakan pada bulan Mei 2013 dengan melibatkan 18 atlet PERSIKU U-18. Penelitian ini merupakan penelitian eksperimental dengan pendekatan crossover study dan termasuk dalam ruang lingkup gizi olahraga. Subjek penelitian diambil secara consecutive sampling setelah terlebih dulu diberikan informed consent secara verbal dan memenuhi kriteria inklusi antara lain berusia 16-18 tahun, tidak sedang cidera atau dalam perawatan dokter, serta tidak memiliki riwayat kesehatan yang berhubungan dengan jantung, paru-paru, maupun diabetes.

Variabel bebas pada penelitian ini adalah minuman madu yang dibuat mendekati waktu pemberian dengan takaran saji $40 \mathrm{ml}$ madu dalam $500 \mathrm{ml}$ air (1:12.5) dan memiliki kadar karbohidrat $8 \%$. Madu yang digunakan merupakan jenis madu merek ' $X$ ' yang dihasilkan oleh koloni lebah ternak (budidaya) di sebuah perkebunan. Dalam larutan ini ditambahkan pula garam sebanyak 1 jumput kecil (setara dengan 0.36 gram) sebagai 
sumber natrium (elektrolit) serta air perasan lemon sebanyak $1 \mathrm{sdm}$ sebagai penambah cita rasa. Minuman ini diberikan sebanyak 6 kali dengan volume $200 \mathrm{ml}$ setiap interval 20 menit selama 100 menit simulasi pertandingan. Sebagai kontrol, pada kesempatan yang berbeda, subjek juga diberikan perlakuan lain berupa pemberian air putih (plasebo) dalam jumlah dan frekuensi yang sama dengan pemberian minuman madu.

Variabel terikat pada penelitian ini adalah kadar glukosa darah yang diukur sebanyak dua kali yakni sebelum dan setelah simulasi pertandingan pada masing-masing perlakuan. Variabel kontrol pada penelitian ini antara lain komposisi tubuh (persen lemak tubuh dan massa tubuh tanpa lemak), serta asupan energi, karbohidrat, protein, dan lemak selama dua hari sampai satu jam menjelang simulasi pertandingan.

Penelitian ini berlangsung selama 14 hari tidak berurutan. Minggu pertama merupakan pelaksanaan informed consent, skrining, pengambilan data antropometri, komposisi tubuh, serta $\mathrm{VO}_{2}$ maks atlet. Intervensi berupa pemberian minuman madu dan air putih dilaksanakan pada minggu kedua, yakni sebanyak 2 kali percobaan simulasi pertandingan dengan jeda waktu antar percobaan selama 1 minggu. Pada percobaan pertama, 9 subjek diberikan minuman madu, sedangkan 9 subjek lainnya diberikan air putih sebagai cairan rehidrasi. Pada percobaan kedua, jenis perlakuan terhadap subjek dibalik.

Data yang dikumpulkan meliputi data antropometri (berat badan dan tinggi badan), komposisi tubuh (persen lemak tubuh dan massa tubuh tanpa lemak), data kapasitas aerobik $\left(\mathrm{VO}_{2}\right.$ maks), data asupan makanan, serta data kadar glukosa darah. Berat badan diukur menggunakan timbangan injak digital dengan ketelitian $0.1 \mathrm{~kg}$. Tinggi badan diukur menggunakan microtoise dengan batas ukur $200 \mathrm{~cm}$ dan ketelitian $0.1 \mathrm{~cm}$. Persen lemak tubuh diukur menggunakan Bioelectric Impedance Analyzer (BIA) dengan merek Omron body fat analyzer digital weighing scale HBF-200. Kapasitas aerobik atlet $\left(\mathrm{VO}_{2}\right.$ maks) diukur melalui tes lari 12 menit (Cooper test). Waktu yang dibutuhkan untuk menyelesaikan tes lari diukur menggunakan stopwatch dengan ketelitian 0.01 detik. Data asupan makanan diperoleh melalui pencatatan formulir food record selama 3 hari sebelum simulasi pertandingan. Pengambilan sampel darah untuk pengukuran kadar glukosa darah dilakukan oleh laboran di laboratorium ' $\mathrm{X}$ ' melalui pembuluh kapiler pada jari dengan menggunakan glucose meter.

Tabel 1. Kronologi prosedur pengambilan data pada periode intervensi

\begin{tabular}{ll}
\hline \multicolumn{1}{c}{ Waktu } & \multicolumn{1}{c}{ Prosedur } \\
\hline $14.30-15.00$ & Pengambilan sampel darah awal (bertempat di laboratorium) \\
15.15 & Subjek mulai diberikan minuman (larutan madu atau air putih) \\
$15.20-17.00$ & Latihan (pemanasan, pertandingan, dan pendinginan). Minuman \\
& diberikan sebanyak 200 ml setiap interval 20 menit. \\
$17.15-17.45$ & Pengambilan sampel darah akhir (bertempat di laboratorium) \\
\hline
\end{tabular}

Subjek datang ke laboratorium 30 menit sebelum simulasi pertandingan dimulai. Sebelumnya, subjek diberikan penjelasan secara verbal untuk tidak mengkonsumsi makanan atau minuman selain air putih selama 1 jam sebelum pengambilan darah awal. Latihan dimulai dengan 20 menit pemanasan, dilanjutkan 70 menit pertandingan (mini game), kemudian 10 menit pendinginan. Pemberian intervensi berupa minuman rehidrasi (madu atau air putih) dimulai pada menit pertama sebelum pemanasan dan berakhir pada menit terakhir setelah pendinginan. Simulasi pertandingan dilaksanakan di lapangan yang berdekatan dengan laboratorium (kurang lebih berjarak 300 meter).

Data yang diperoleh dianalisis secara statistik menggunakan program komputer SPSS 17.0 for Windows. Analisis deskriptif digunakan untuk melihat gambaran karakteristik subjek. Analisis bivariate diawali dengan uji normalitas data Shapiro-Wilk, kemudian dilanjutkan dengan uji beda paired t-test apabila data berdistribusi normal, dan uji Wilcoxon apabila data tidak berdistribusi normal. Analisis korelatif untuk mengetahui hubungan pengaruh antara variabel menggunakan uji Pearson untuk data berdistribusi normal dan Spearman untuk data tidak berdistribusi normal. Data asupan makan dianalisis menggunakan program komputer Nutrisurvey.

\section{HASIL PENELITIAN}

Sebanyak 24 atlet yang memenuhi kriteria inklusi bersedia mengikuti program penelitian setelah diberikan informed consent. Percobaan pertama intervensi, 21 atlet datang pada simulasi pertandingan. Namun, percobaan kedua intervensi, 
3 atlet tidak datang pada simulasi pertandingan, sehingga jumlah atlet yang mengikuti rangkaian intervensi secara lengkap sebanyak 18 orang.

\section{Karakteristik Subjek Penelitian}

Karakteristik subjek penelitian yang meliputi usia, berat badan, tinggi badan, Indeks Massa Tubuh, persen lemak tubuh, massa tubuh tanpa lemak, $\mathrm{VO}_{2}$ maks, frekuensi latihan, serta lama latihan disajikan dalam tabel 2.

Tabel 2. Karakteristik subjek penelitian $(\mathrm{n}=18)$

\begin{tabular}{lccc}
\hline \multicolumn{1}{c}{ Karakteristik } & Minimal & Maksimal & Rerata \pm SB \\
\hline Usia (tahun) & 16 & 18 & $16.61 \pm 0.69$ \\
Berat badan $(\mathrm{kg})$ & 43.90 & 78.10 & $57.74 \pm 8.22$ \\
Tinggi badan $(\mathrm{cm})$ & 155.50 & 177.00 & $165.86 \pm 5.39$ \\
Indeks Massa Tubuh $\left(\mathrm{kg} / \mathrm{m}^{2}\right)$ & 15.90 & 29.00 & $20.93 \pm 2.66$ \\
Persen lemak tubuh $(\%)$ & 6.20 & 26.30 & $15.91 \pm 4.27$ \\
Massa tubuh tanpa lemak $(\mathrm{kg})$ & 41.13 & 57.85 & $48.15 \pm 5.31$ \\
$\mathrm{VO}_{2}$ maks $(\mathrm{ml} / \mathrm{kg} /$ menit) & 32.53 & 51.64 & $43.62 \pm 6.09$ \\
Frekuensi latihan per minggu & 3 & 6 & $4.65 \pm 0.78$ \\
(...kali) & 4.5 & 9.0 & $6.8 \pm 1.17$ \\
Lama latihan per minggu (jam) & & & \\
\hline
\end{tabular}

Rerata Indeks Massa Tubuh subjek adalah $20.93 \pm 2.66 \mathrm{~kg} / \mathrm{m}^{2}$. Berdasarkan acuan terhadap kurva persentil Indeks Massa Tubuh menurut umur (5-19 tahun), diketahui bahwa 15 subjek (83.33\%) memiliki status gizi normal. Tiga subjek sisanya masing-masing memiliki Indeks Massa Tubuh dengan kategori kekurangan berat badan tingkat ringan (IMT $=18$ ), kekurangan berat badan tingkat berat $(\mathrm{IMT}=15.9)$, serta kelebihan berat badan tingkat berat $(\mathrm{IMT}=29.0)$.

Rerata persen lemak tubuh subjek sebesar $15.91 \pm 4.27$. Sebagian besar subjek $(72.22 \%)$ memiliki persen lemak tubuh normal atau sesuai dengan proporsi lemak tubuh untuk atlet sepak bola yakni berada pada rentang $8-18 \%$. Satu subjek memiliki persen lemak tubuh di bawah nilai normal, sedangkan 4 subjek (22.22\%) memiliki persen lemak tubuh di atas nilai normal. Nilai massa tubuh tanpa lemak (lean body mass) subjek didapatkan dengan cara perhitungan, yakni selisih antara berat badan aktual dengan persen lemak (\%). Rerata massa tubuh tanpa lemak subjek sebesar $48.15 \pm 5.31 \mathrm{~kg}$.

Rerata nilai $\mathrm{VO}_{2}$ maks subjek sebesar 43.62 \pm 6.09 dan termasuk dalam kategori cukup.
Sebanyak $44.44 \%$ subjek memiliki kategori nilai $\mathrm{VO}_{2}$ maks baik, 2 subjek (11.11\%) memiliki kategori $\mathrm{VO}_{2}$ maks baik sekali, sementara $22.22 \%$ subjek berada pada kategori $\mathrm{VO}_{2}$ maks kurang. Sebagian besar subjek $(55.56 \%)$ berlatih sepak bola sebanyak 5 kali per minggu dengan durasi total 7 jam $(6.8 \pm 1.17$ jam $)$. Nilai maksimum frekuensi latihan subjek yakni 6 kali per minggu, sedangkan nilai minimum 3 kali per minggu. Datadata tersebut menunjukkan bahwa sebagian besar subjek memiliki tingkat aktivitas cukup berat dan terbiasa dengan latihan intensif.

\section{Gambaran Asupan Makanan Sebelum Intervensi}

Faktor yang berpengaruh terhadap kadar glukosa darah selama latihan atau pertandingan adalah asupan energi, karbohidrat, protein, dan lemak. Data asupan makanan subjek yang dianalisis adalah data asupan makanan selama dua hari sebelum simulasi pertandingan serta asupan makanan yang terhitung dari pagi sampai 1 jam menjelang simulasi pertandingan untuk masingmasing perlakuan.

Tabel 3. Perbedaan asupan energi, karbohidrat, protein, dan lemak subjek sebelum simulasi pertandingan pada kedua jenis perlakuan

\begin{tabular}{|c|c|c|c|c|}
\hline \multirow{2}{*}{ Variabel } & \multicolumn{2}{|c|}{ Rerata \pm SB } & \multirow{2}{*}{$\mathrm{N}$} & \multirow{2}{*}{$P$} \\
\hline & Madu & Air putih $(p l a)$ & & \\
\hline Asupan energi 2 hari sebelum & $1802.00 \pm 420.43$ & $1829.96 \pm$ & 1 & $0.711^{\mathrm{b}}$ \\
\hline Asupan karbohidrat 2 hari & $254.94 \pm 80.35$ & 455.60 & 8 & $0.528^{\mathrm{b}}$ \\
\hline sebelum & $53.33 \pm 15.89$ & $255.57 \pm 89.22$ & 1 & $0.456^{\mathrm{a}}$ \\
\hline Asupan protein 2 hari sebelum & $63.49 \pm 18.87$ & $55.60 \pm 17.30$ & 8 & $0.715^{\mathrm{a}}$ \\
\hline
\end{tabular}




\begin{tabular}{lcccc}
\hline Asupan lemak 2 hari sebelum & $1046.36 \pm 287.27$ & $65.18 \pm 14.65$ & 1 & $0.660^{\mathrm{a}}$ \\
Asupan energi menjelang & $138.32 \pm 34.14$ & $1019.84 \pm$ & 8 & $0.396^{\mathrm{b}}$ \\
Asupan karbohidrat menjelang & $35.63 \pm 16.42$ & 192.98 & 1 & $0.408^{\mathrm{a}}$ \\
Asupan protein menjelang & $38.47 \pm 18.56$ & $141.60 \pm 42.36$ & 8 & $0.824^{\mathrm{a}}$ \\
Asupan lemak menjelang & & $32.13 \pm 7.30$ & 1 & \\
& & $37.38 \pm 11.01$ & 8 & \\
& & & 1 & \\
& & & 8 & \\
& & & 1 & \\
& & & 8 & \\
& & & 1 & \\
\end{tabular}

${ }^{a}$ paired t-test, terdapat perbedaan yang bermakna $(p<0.05)$

${ }^{\mathrm{b}}$ Wilcoxon, terdapat perbedaan yang bermakna $(p<0.05)$

Berdasarkan analisis menggunakan uji beda paired t-test dan Wilcoxon, diperoleh hasil bahwa terdapat perbedaan yang tidak bermakna pada asupan energi, karbohidrat, protein, dan lemak baik sebelum perlakuan minuman madu maupun air putih ( $\mathrm{p}>$ 0.05). Dengan demikian, dapat disimpulkan bahwa asupan energi, karbohidrat, protein, dan lemak subjek sebelum simulasi pertandingan untuk masing-masing perlakuan adalah sama.

\section{Kadar Glukosa Darah Sebelum dan Setelah Simulasi Pertandingan}

Perbedaan kadar glukosa darah sebelum dan setelah simulasi pertandingan pada perlakuan minuman madu maupun air putih disajikan dalam tabel 4 .

Tabel 4. Perbedaan kadar glukosa darah sebelum dan setelah simulasi pertandingan pada masing-masing perlakuan

\begin{tabular}{|c|c|c|c|c|c|c|}
\hline \multirow[b]{2}{*}{ Variabel } & \multicolumn{4}{|c|}{ Rerata \pm SB } & \multirow[b]{2}{*}{$\Delta$} & \multirow[b]{2}{*}{$p^{c}$} \\
\hline & $\begin{array}{c}\text { Sebelum } \\
\text { Pertandingan }\end{array}$ & $\mathrm{p}^{\mathrm{a}}$ & $\begin{array}{c}\text { Setelah } \\
\text { Pertandingan } \\
\end{array}$ & $\mathrm{p}^{\mathrm{b}}$ & & \\
\hline $\begin{array}{l}\text { Kadar } \\
\text { glukosa } \\
\text { darah }\end{array}$ & $105.28 \pm 25.12$ & & $103.39 \pm 18.91$ & & $-1.89 \pm 34.17$ & 0.817 \\
\hline $\begin{array}{l}(\mathrm{mg} / \mathrm{dl}): \\
\text { madu } \\
\text { air putih }\end{array}$ & $112.44 \pm 11.97$ & $\begin{array}{l}0.88 \\
5\end{array}$ & $101.22 \pm 14.63$ & $\begin{array}{l}0.24 \\
6\end{array}$ & $\begin{array}{ll}-11.22 & \pm \\
17.25 & \end{array}$ & 0.013 \\
\hline
\end{tabular}

\footnotetext{
(pla)

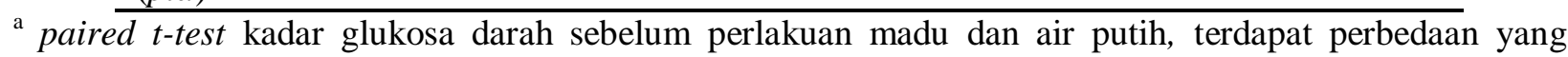
bermakna $(\mathrm{p}<0.05)$

${ }^{\mathrm{b}}$ paired t-test kadar glukosa darah setelah perlakuan madu dan air putih, terdapat perbedaan yang bermakna $(\mathrm{p}<0.05)$

${ }^{c}$ paired t-test kadar glukosa darah sebelum dan setelah simulasi pertandingan pada kedua perlakuan, terdapat perbedaan yang bermakna $(\mathrm{p}<0.05)$
}

Uji beda menggunakan paired t-test menunjukkan bahwa terdapat perbedaan yang tidak bermakna pada kadar glukosa darah sebelum dan setelah simulasi pertandingan baik pada perlakuan minuman madu maupun air putih ( $\mathrm{p}>0.05)$. Dengan demikian, kondisi subjek dalam hal kadar glukosa darah sebelum dan setelah simulasi pertandingan pada masing-masing perlakuan adalah sama.
Hasil uji paired t-test menunjukkan bahwa terdapat perbedaan yang tidak bermakna antara kadar glukosa darah sebelum dan setelah simulasi pertandingan pada perlakuan minuman madu $(\mathrm{p}=$ 0.817 ), namun terdapat perbedaan yang bermakna antara kadar glukosa darah sebelum dan setelah simulasi pertandingan pada perlakuan air putih ( $\mathrm{p}$ $=0.013$ ). Terdapat penurunan kadar glukosa darah selama simulasi pertandingan sebanyak $1.89 \pm$ $34.17 \mathrm{mg} / \mathrm{dl}$ pada perlakuan minuman madu, 
sedangkan pada perlakuan air putih penurunan kadar glukosa darah sebesar $11.22 \pm 0.013 \mathrm{mg} / \mathrm{dl}$.

Hubungan Antara Komposisi Tubuh dan Asupan Makan dengan Kadar Glukosa Darah

Komposisi tubuh (persen lemak tubuh dan massa tubuh tanpa lemak) serta asupan makanan sebelum simulasi pertandingan merupakan variabel perancu (kontrol) dalam penelitian ini. Hasil analisis korelatif variabel tersebut dengan kadar glukosa darah selama simulasi pertandingan disajikan dalam tabel 5 dan tabel 6.

Tabel 5. Korelasi komposisi tubuh dengan kadar glukosa darah

\begin{tabular}{llllll}
\hline \multirow{2}{*}{ Komposisi tubuh } & \multicolumn{4}{c}{ Kadar glukosa darah } \\
\cline { 2 - 5 } & \multicolumn{2}{c}{ Madu } & \multicolumn{2}{c}{ Air putih } \\
\cline { 2 - 5 } & \multicolumn{2}{c}{ Sebelum } & Setelah & Sebelum & Setelah \\
Persendingan lemak tubuh & Pertandingan & Pertandingan & Pertandingan \\
& $\mathrm{r}$ & -0.225 & 0.307 & 0.113 & 0.178 \\
& $\mathrm{p}$ & 0.369 & 0.215 & 0.656 & 0.481 \\
Massa tubuh tanpa lemak & & & & \\
& $\mathrm{r}$ & -0.147 & 0.286 & 0.487 & 0.039 \\
$\mathrm{p}$ & 0.559 & 0.250 & 0.040 & 0.878 \\
\hline
\end{tabular}

Korelasi Pearson, terdapat hubungan yang bermakna $(p<0.05)$

Tabel 5 menunjukkan bahwa terdapat hubungan yang tidak bermakna antara persen lemak tubuh dengan kadar glukosa darah sebelum dan setelah simulasi pertandingan pada kedua jenis perlakuan $(\mathrm{p}>0.05)$. Tidak terdapat hubungan yang bermakna antara massa tubuh tanpa lemak dengan kadar glukosa darah sebelum dan setelah simulasi pertandingan pada perlakuan madu ( $\mathrm{p}>$ 0.05), namun terdapat hubungan yang bermakna dengan kadar glukosa darah sebelum perlakuan air putih ( $<$ 0.05). Secara umum, komposisi tubuh tidak berpengaruh terhadap kadar glukosa darah selama simulasi pertandingan.

Tabel 6. Korelasi asupan makanan sebelum simulasi pertandingan dengan kadar glukosa darah

\begin{tabular}{|c|c|c|c|c|}
\hline \multirow{3}{*}{ Asupan makanan } & \multicolumn{4}{|c|}{ Kadar glukosa darah } \\
\hline & \multicolumn{2}{|c|}{ Madu } & \multicolumn{2}{|c|}{ Air putih } \\
\hline & Sebelum & Setelah & Sebelum & Setelah \\
\hline \multicolumn{5}{|c|}{$\begin{array}{l}\text { Rerata asupan energi } 2 \text { hari } \\
\text { sebelum }\end{array}$} \\
\hline & $0.294^{\mathrm{b}}$ & $0.065^{\mathrm{b}}$ & $0.422^{\mathrm{b}}$ & $0.407^{\mathrm{b}}$ \\
\hline & $0.237^{\mathrm{b}}$ & $0.797^{\mathrm{b}}$ & $0.081^{b}$ & $0.094^{\mathrm{b}}$ \\
\hline
\end{tabular}

Rerata asupan KH 2 hari sebelum

$\begin{array}{ccccc}\mathrm{r} & 0.006^{\mathrm{b}} & 0.127^{\mathrm{b}} & 0.174^{\mathrm{b}} & 0.286^{\mathrm{b}} \\ \mathrm{p} & 0.980^{\mathrm{b}} & 0.615^{\mathrm{b}} & 0.490^{\mathrm{b}} & 0.249^{\mathrm{b}} \\ \text { Rerata asupan protein } 2 & & & & \end{array}$

hari sebelum

Rerata asupan lemak 2 hari

$\begin{array}{lllll}\mathrm{r} & 0.130^{\mathrm{a}} & 0.065^{\mathrm{a}} & 0.401^{\mathrm{a}} & 0.265^{\mathrm{a}} \\ \mathrm{p} & 0.607^{\mathrm{a}} & 0.798^{\mathrm{a}} & 0.099^{\mathrm{a}} & 0.288^{\mathrm{a}}\end{array}$

sebelum

$\begin{array}{lllll}\mathrm{r} & 0.713^{\mathrm{a}} & -0.062^{\mathrm{a}} & 0.624^{\mathrm{a}} & 0.055^{\mathrm{a}} \\ \mathrm{p} & 0.001^{\mathrm{a}} & 0.806^{\mathrm{a}} & 0.006^{\mathrm{a}} & 0.830^{\mathrm{a}}\end{array}$

Asupan energi pagi - 1 jam menjelang 


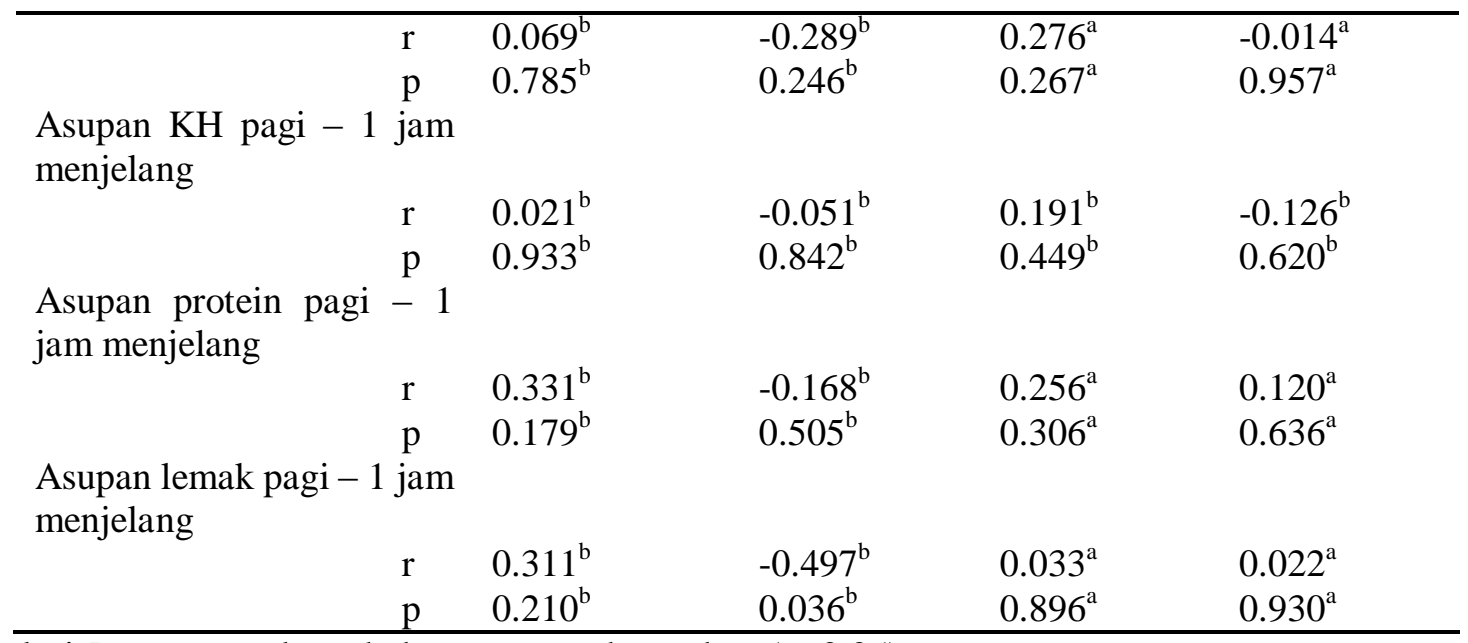

${ }^{a}$ Korelasi Pearson, terdapat hubungan yang bermakna $(\mathrm{p}<0.05)$

${ }^{\mathrm{b}}$ Korelasi Spearman, terdapat hubungan yang bermakna $(\mathrm{p}<0.05)$

Uji korelasi antar variabel tersebut menunjukkan bahwa secara umum, asupan energi, karbohidrat, dan protein sebelum simulasi pertandingan tidak memiliki hubungan yang bermakna dengan kadar glukosa darah sebelum dan setelah simulasi pertandingan pada masingmasing perlakuan $(\mathrm{p}>0.05)$. Namun, rerata asupan lemak 2 hari sebelum simulasi pertandingan memiliki korelasi yang bermakna dengan kadar glukosa darah awal (sebelum pertandingan) pada kedua jenis perlakuan dengan koefisien korelasi yang kuat. Hal ini menunjukkan bahwa semakin tinggi asupan lemak, maka semakin tinggi pula kadar glukosa darah sebelum simulasi pertandingan.

Terdapat korelasi negatif yang tidak bermakna antara rerata asupan lemak 2 hari sebelum intervensi dengan kadar glukosa darah akhir (setelah pertandingan) pada perlakuan madu. Korelasi negatif ditemukan pula pada hubungan asupan energi dan karbohidrat menjelang intervensi dengan kadar glukosa darah akhir pada kedua perlakuan, serta hubungan asupan protein sebelum intervensi dengan kadar glukosa darah akhir pada perlakuan madu. Korelasi negatif yang kuat ditemukan pada hubungan asupan lemak menjelang intervensi dengan kadar glukosa darah akhir pada perlakuan madu. Adanya korelasi negatif menunjukkan bahwa semakin tinggi asupan energi, karbohidrat, protein, dan lemak sebelum intervensi, maka kadar glukosa darah setelah pertandingan semakin turun.

\section{PEMBAHASAN}

Penelitian ini melibatkan 18 subjek yang terbagi dalam 2 kelompok perlakuan dan menjalani 2 kali masa intervensi. Seluruh subjek menerima kedua jenis intervensi pada 2 kesempatan yang berbeda. Desain penelitian Crossover yang mengharuskan subjek memperoleh kedua jenis perlakuan dimaksudkan agar subjek bertindak sebagai kontrol terhadap dirinya sendiri dan menghilangkan varian subjek, sehingga bias karakteristik subjek dapat ditekan. Efek carry-over yang merupakan kelemahan desain Crossover dianggap tidak terjadi karena perlakuan berupa pemberian minuman selama simulasi pertandingan yang dapat langsung diserap tubuh dan hilang bersama keringat. Jeda waktu antar percobaan (periode wash-out) selama satu minggu bertujuan memberikan subjek cukup waktu untuk pemulihan, serta agar kedua percobaan dalam simulasi pertandingan dapat dilaksanakan pada hari yang sama. Pemilihan hari dan waktu simulasi pertandingan yang sama bertujuan untuk memperkecil varian akibat pengaruh irama circardian.

Subjek penelitian merupakan remaja lakilaki berusia 16-18 tahun. Pemilihan remaja lakilaki didasarkan pada teori yang menyatakan bahwa remaja laki-laki mengalami pertumbuhan massa otot yang lebih banyak dan memiliki komposisi lemak tubuh yang cenderung sedikit. ${ }^{21}$ Usia remaja dikarakteristikkan pula sebagai kelompok usia yang resisten terhadap insulin, memiliki respon metabolik (glikolitik) yang berbeda selama latihan, serta memiliki laju oksidasi lemak yang cenderung lebih tinggi dibanding usia dewasa. Masa pubertas berkaitan pula dengan rendahnya kapasitas penyimpanan glikogen. ${ }^{22}$ Insulin berperan penting pada masa pubertas, dan berpengaruh terhadap respon terhadap glukosa selama latihan. ${ }^{22}$

Sebagian besar subjek $(72.22 \%)$ memiliki komposisi lemak tubuh normal $(15.91 \pm 4.27 \%)$ 
atau sesuai dengan proporsi atlet sepak bola yakni berada pada rentang 8-18\%. Komposisi tubuh berpengaruh terhadap kadar glikogen otot, sehingga berpengaruh pula terhadap kadar glukosa darah. Glukosa darah dapat dipecah dari cadangan glikogen otot apabila tubuh membutuhkan. Komposisi tubuh berhubungan dengan persentase ukuran lemak tubuh dan bentuk tubuh. Semakin sedikit persentase lemak tubuh dan semakin besar massa otot, maka semakin besar pula simpanan glikogen dalam tubuh. ${ }^{3}$ Namun, berdasarkan uji korelasi variabel komposisi tubuh dengan kadar glukosa darah, diperoleh hasil bahwa komposisi tubuh (persen lemak tubuh dan massa tubuh tanpa lemak) tidak memiliki hubungan yang bermakna dengan kadar glukosa darah selama simulasi pertandingan.

Rerata asupan makanan subjek selama 2 hari sebelum simulasi pertandingan pada masingmasing perlakuan antara lain 1802-1830 kkal energi, 255-256 gram karbohidrat, 53.3-55.6 gram protein, serta 63.5-65 gram lemak. Sementara, asupan makanan pada hari perlakuan terhitung dari pagi hingga 1 jam sebelum simulasi pertandingan antara lain 1020-1046 kkal energi, 138-142 gram karbohidrat, 32-36 gram protein, serta 37-38 gram lemak. Jumlah asupan makanan subjek jauh di bawah rerata kebutuhan energi yakni 3670 kkal energi, 550 gram karbohidrat, 138 gram protein, serta 102 gram lemak. Asupan energi terutama karbohidrat yang adekuat beberapa jam atau beberapa hari menjelang latihan dapat meminimalisasi pemecahan jaringan otot. Asupan tinggi karbohidrat dapat meningkatkan simpanan glikogen dalam hati dan otot. Sebaliknya, asupan karbohidrat yang rendah dapat menurunkan kadar glikogen. ${ }^{3}$

Sebanyak 2 subjek $(11,1 \%)$ memiliki Indeks Massa Tubuh di bawah nilai normal. Kurangnya Indeks Massa Tubuh kemungkinan disebabkan ketidakseimbangan antara asupan energi dengan tingkat aktivitas. Asupan energi subjek berada di bawah kebutuhan, sehingga cadangan energi melalui makanan tidak cukup untuk menggantikan energi yang dikeluarkan pada saat aktivitas berlatih sepak bola. Satu subjek memiliki Indeks Massa Tubuh melebihi nilai normal $($ IMT $=29)$. Dari hasil analisis terhadap asupan makanan, diketahui bahwa asupan energi subjek berada di bawah kebutuhan. Terdapat faktor lain yang kemungkinan berpengaruh terhadap tingginya Indeks Massa Tubuh antara lain genetik dan tingkat aktivitas. Selain itu, pencatatan food record hanya berlangsung selama penelitian, sehingga tidak dapat menggambarkan kebiasaan makan subjek. Kebiasaan makan dapat menggambarkan asupan energi subjek, dan secara langsung berpengaruh terhadap Indeks Massa Tubuh.

Meskipun secara teoritis, asupan energi berpengaruh terhadap kadar glukosa darah. Namun, berdasarkan uji korelasi variabel asupan makanan dengan kadar glukosa darah, diperoleh hasil bahwa secara keseluruhan, tidak terdapat hubungan yang bermakna antara asupan energi, karbohidrat, dan protein sebelum simulasi pertandingan dengan kadar glukosa darah. Terdapat korelasi negatif yang tidak bermakna antara asupan energi, karbohidrat, protein, dan lemak dengan kadar glukosa darah setelah simulasi pertandingan. Korelasi negatif tersebut menunjukkan bahwa semakin tinggi asupan (energi, karbohidrat, protein, dan lemak) sebelum intervensi, maka kadar glukosa darah setelah pertandingan semakin turun. Penurunan kadar glukosa darah terjadi akibat mekanisme pemecahan energi selama pertandingan. Selain itu, penambahan asupan lemak dan protein ke dalam karbohidrat dapat menurunkan respon glikemik melalui mekanisme penundaan pengosongan lambung dan stimulasi sekresi insulin, sehingga kadar glukosa darah tidak cepat mengalami penaikan. ${ }^{23}$

Selain komposisi tubuh dan asupan makanan, kadar glukosa darah selama latihan atau pertandingan juga dapat dipengaruhi oleh lama dan intensitas latihan, konsumsi karbohidrat berindeks glikemik tinggi menjelang latihan atau pertandingan, konsumsi karbohidrat selama latihan atau pertandingan, serta pengaruh hormonal.

Lama latihan berpengaruh terhadap kadar glukosa darah selama latihan. Pada latihan berintensitas ringan, seperti $30-50 \%$ dari $\mathrm{VO}_{2}$ maks, sumber energi utama yang digunakan adalah lemak, sehingga penggunaan karbohidrat tidak besar. Pada latihan berintensitas ringan, glukoneogenesis dapat membantu mempertahankan kadar glukosa darah di atas kadar hipoglikemia. Namun, pada latihan yang berintensitas $50-60 \%$ dari $\mathrm{VO}_{2}$ maks atau lebih, penggunaan glikogen otot meningkat, sehingga lebih banyak glukosa darah digunakan, dan proses glukoneogenesis tidak cukup cepat untuk mengganti glikogen yang hilang. ${ }^{4}$ Latihan juga dapat meningkatkan sensitivitas insulin, sehingga lebih banyak glukosa yang disalurkan ke otot yang membutuhkan. Dengan demikian, kadar insulin menurun selama latihan untuk membantu mempertahankan kadar glukosa darah yang 
normal. ${ }^{24}$ Berdasarkan pertimbangan tersebut, pada dua kali masa intervensi, lama latihan (simulasi pertandingan) dipertahankan sama, yakni berdurasi 100 menit, dan termasuk ke dalam kategori intensitas tinggi. $\mathrm{VO}_{2}$ maks menggambarkan seberapa jauh subjek dapat mengoptimalkan kapasitas aerobiknya dibandingkan dengan intensitas latihan.

Konsumsi sumber karbohidrat berindeks glikemik tinggi sesaat sebelum latihan atau selama latihan dapat meningkatkan kadar glukosa darah secara cepat, dan memungkinkan terjadinya hiperglikemia (> $140 \mathrm{mg} / \mathrm{dl}){ }^{3}$ Hal ini dipicu oleh peningkatan sekresi insulin oleh pankreas. Namun, tingginya kadar insulin dalam darah dapat mengakibatkan peningkatan transport glukosa darah ke jaringan tubuh secara berlebihan sehingga menyebabkan kadar glukosa darah menurun drastis (hipoglikemia). ${ }^{3}$ Untuk mencegah hal tersebut, subjek diberikan penjelasan secara verbal serta diingatkan kembali melalui pesan singkat untuk tidak mengkonsumsi makanan atau minuman selain air putih selama satu jam menjelang simulasi pertandingan. Pada saat subjek datang ke laboratorium untuk pengambilan sampel darah awal, subjek ditanya mengenai waktu makan terakhir. Tidak ada subjek yang mengkonsumsi makanan dalam rentang satu jam menjelang pengambilan sampel darah. Namun, waktu makan terakhir subjek sebelum pengambilan sampel darah awal berbeda-beda, yakni berada pada rentang 14.5 jam. Perbedaan waktu makan ini berpengaruh terhadap kadar glukosa darah awal (sebelum simulasi pertandingan). Pada individu normal, kadar glukosa darah mencapai puncak pada 1 jam setelah makan, dan kembali pada kondisi preprandial dalam 2-3 jam. Namun, glukosa darah postprandial berfluktuasi bergantung pada jenis makanan yang diasup, kuantitas makanan, serta tingkat aktivitas fisik. ${ }^{25}$

Penelitian-penelitian terdahulu telah banyak membuktikan bahwa pemberian minuman berkarbohidrat 6-8\% selama latihan atau pertandingan dapat meningkatkan performa dengan menunda kelelahan. ${ }^{3,4,9-15}$ Madu merupakan sumber karbohidrat alami yang dapat bertindak sebagai penyuplai energi selama olahraga. Madu berpotensi sebagai ergogenic aid alami dalam olahraga dikarenakan memiliki kadar karbohidrat yang tinggi terutama jenis fruktosa dan glukosa, serta adanya kandungan zat gizi lain seperti asam amino, beberapa vitamin, mineral, dan antioksidan. Keberadaan dua jenis karbohidrat yakni glukosa dan fruktosa pada madu dalam jumlah seimbang dapat memberikan keuntungan apabila dikonsumsi sebagai minuman olahraga. Kombinasi dua jenis karbohidrat tersebut apabila dikonsumsi bersamaan dapat meningkatkan total oksidasi karbohidrat eksogen. ${ }^{26}$ Larutan yang mengandung beberapa jenis karbohidrat seperti glukosa dan fruktosa menunjukkan efek peningkatan absorpsi, oksidasi, dan performa dibanding larutan yang hanya mengandung satu jenis karbohidrat. ${ }^{27}$

Di samping peran karbohidrat sebagai sumber energi selama berolahraga, natrium dan kalium sebagai sumber elektrolit dapat membantu absorpsi glukosa dengan cepat apabila ditambahkan bersama sumber karbohidrat dalam minuman. ${ }^{3}$ Kadar natrium sebanyak 20-50 mmol/1 $(460-1150 \mathrm{mg} / \mathrm{l})$ dapat menstimulasi pemakaian karbohidrat dan air dalam usus halus dan mempertahankan volume cairan ekstraseluler. ${ }^{3}$ Oleh karena itu, dalam formulasi minuman berkarbohidrat, garam sebagai sumber natrium dapat ditambahkan sebanyak satu jumput kecil atau setara dengan 0.36 gram. Sementara itu, untuk meningkatkan palatabilitas, dalam larutan dapat ditambahkan perasan lemon. Jumlah yang digunakan yakni $1 / 2 \mathrm{sdm}$. Kadar natrium pada minuman ini hanya sebesar $0.9 \mathrm{mg} / \mathrm{l}$, dan kadar kalium sebesar $0.18 \mathrm{mg} / \mathrm{l}$. Dengan demikian, kadar natrium dan kalium sebagai sumber elektrolit dalam minuman madu sebagaimana berperan dalam mempercepat absorpsi karbohidrat tidak dapat dijadikan sebagai parameter penelitian. Jumlah karbohidrat dalam minuman madu yang bertindak sebagai sumber energi selama latihan sepak bola menjadi fokus penelitian.

Hasil uji paired t-test menunjukkan bahwa terjadi penurunan kadar glukosa darah selama simulasi pertandingan sebanyak $1.89 \pm 34.17$ $\mathrm{mg} / \mathrm{dl}$ pada perlakuan minuman madu, sedangkan pada perlakuan air putih penurunan kadar glukosa darah sebesar $11.22 \pm 0.013 \mathrm{mg} / \mathrm{dl}$. Dengan demikian, hasil tersebut sesuai dengan penelitianpenelitian sebelumnya yang menyatakan bahwa pemberian minuman dengan kandungan karbohidrat 6-8\% selama latihan atau pertandingan dapat membantu mempertahankan kadar glukosa darah. ${ }^{4,5} 10-16$ Beberapa penelitian yang dilakukan pada atlet balap sepeda menyebutkan bahwa atlet yang mengkonsumsi minuman berkarbohidrat selama latihan memiliki kadar glukosa darah lebih stabil dibanding kelompok plasebo. . $^{19,20}$

Penelitian menggunakan larutan madu pernah dilakukan pada atlet gulat dengan mencoba menurunkan suhu tubuh dan mempertahankan kadar glukosa darah. Hasil yang diperoleh 
menunjukkan bahwa larutan madu memberikan pengaruh signifikan dalam mempertahankan kadar glukosa darah dan menurunkan suhu tubuh selama latihan. $^{27}$ Pada percobaan lain, efektivitas pemberian gel karbohidrat dengan indeks glikemik rendah (madu) dan tinggi (glukosa) terhadap performa dilakukan pada atlet balap sepeda $64 \mathrm{~km}$. Hasil yang diperoleh menunjukkan bahwa baik gel yang memiliki indeks glikemik rendah maupun tinggi dapat meningkatkan performa bersepeda, dan efektivitas madu sedikit lebih baik dibanding glukosa. ${ }^{28,29}$

Penelitian yang dilakukan di laboratorium University of Memphis Exercise and Sports Nutrition mengemukakan bahwa madu merupakan salah satu bentuk karbohidrat yang paling efektif untuk dikonsumsi sesaat sebelum latihan atau olahraga. Penelitian lebih lanjut menemukan bahwa, sebagai sumber energi, peranan madu hampir sejajar dengan glukosa (sumber karbohidrat pada sebagian besar produk sport drink komersial). Madu dan sport drink komersial menawarkan karbohidrat dalam jumlah yang hampir sama. Namun, sport drink dapat mengandung bahan pengawet buatan, pewarna, dan pemanis, serta kurang dalam hal vitamin dan mineral seperti yang terkandung pada madu. ${ }^{29}$

Keterbatasan penelitian ini antara lain tidak dilaksanakannya kontrol (standarisasi) terhadap asupan makanan serta aktivitas fisik subjek sebelum intervensi, sehingga kemungkinan menyebabkan kadar glukosa darah subjek sebelum simulasi pertandingan bervariasi. Keterbatasan lainnya yakni pengukuran persen lemak tubuh menggunakan BIA injak yang belum dapat menggambarkan keseluruhan persen lemak tubuh secara pasti. Tidak dilaksanakannya pengukuran kadar insulin dan glukagon, hormon yang berperan dalam metabolisme glukosa selama latihan atau pertandingan juga merupakan keterbatasan penelitian ini.

\section{SIMPULAN}

Terdapat perbedaan yang tidak bermakna antara kadar glukosa darah sebelum dan setelah simulasi pertandingan pada perlakuan minuman madu $(\mathrm{p}=0.817)$, namun terdapat perbedaan yang bermakna antara glukosa darah sebelum dan setelah simulasi pertandingan pada perlakuan air putih $(\mathrm{p}=0.013)$. Terdapat penurunan kadar glukosa darah selama simulasi pertandingan sebanyak $1.89 \pm 34.17 \mathrm{mg} / \mathrm{dl}$ pada perlakuan minuman madu, sedangkan pada perlakuan air putih penurunan kadar glukosa darah sebesar 11.22 $\pm 0.013 \mathrm{mg} / \mathrm{dl}$. Minuman madu lebih efektif dalam mempertahankan kadar glukosa darah selama simulasi pertandingan dibanding air putih (plasebo).

\section{SARAN}

Pemberian minuman madu dengan konsentrasi $8 \%$ dapat diterapkan pada atlet yang menjalani latihan atau pertandingan sebagai sumber energi, terutama apabila latihan atau pertandingan berlangsung lebih dari 1 jam.

\section{UCAPAN TERIMA KASIH}

Puji syukur penulis panjatkan kepada Allah SWT atas limpahan rahmat-Nya kepada penulis. Penulis berterima kasih kepada pengurus PERSIKU U-18, para pelatih, serta pemain yang telah bekerjasama dan membantu penulis dalam pelaksanaan penelitian ini. Ucapan terima kasih penulis sampaikan pula kepada dosen pembimbing, dr. Etisa Adi Murbawani, M. Si, atas bimbingan yang telah diberikan, serta dosen penguji yang telah memberikan masukan dan saran kepada penulis. Terima kasih kepada orang tua, temanteman, serta pihak lain yang terlibat dalam penelitian ini.

\section{DAFTAR PUSTAKA}

1. Williams MA. Science and soccer: developing elite performers. New York: Routledge Publishers; 2013. p3,8.

2. Tomas S, Karim C, Calro C, Ulrik W. Physiology of soccer: an update. Sports Med. [serial online] 2005 [dikutip 2012 Okt 1] ; 35(6) : 501-36. TersediaURL:http://www.skautingtimdif.rs/bibliot eka_trening/Physiology_soccer_Update.pdf

3. Heater HF, Lisa AB, Alan EM. Practical application in sports nutririon. Massachusetts: Jones and Bartlett Publisher; 2006. p82-83;224226;326;434;470-475

4. Williams MH. Nutrition for health, fitness, and sport. $8^{\text {th }}$ edition. New York: Mc Graw-Hill Companies, inc; 2007. p 118$120 ; 122 ; 124 ; 125 ; 128 ; 129 ; 131$

5. Krustrup P, Mohri M, Steensberg A, Bencke J, Kjaer M. Muscle and blood metabolites during a soccer game: implications for sprint performance. Med. Sci. Sports Exerc 2006; 10:1

6. Monteiro CR, Guerra I, Barros TL. Hydration in soccer: a review. Rev Bras Med Esporte 2003; 9: 243-6.

7. Maughan RJ, Shirreffs SM, Merson SJ, Horswell CA. Fluid and electrolyte balance in elite male football (soccer) players training in a cold environment. J Sport Sci 2005; 23:73-9. 
8. Coyle EF. Fluid and fuel intake during exercise. J Sports Sci 2004; 22,39-55. p.40-3.

9. Position of the American Dietetic Association, Dietitians of Canada, and the American College of Sports Medicine. Nutrition and athletic performance. J Am Diet Assoc; 2009. p. 509-513.

10. Sizer F, Whitney E. Nutrition concepts and controversies. 10th Ed. USA : Thomson Wadsworth; 2006. p. 359-92.

11. Ostojic SM, Mazic S. Effects of carbohydrateelectrolyte drink on specific soccer tests and performance. J Sport Science Med 2002; 1, 47-53. p. 47-8.

12. Ajmol A, Clyde W, Ceri WN, Andrew F. The influence of carbohydrate-electrolyte ingestion on soccer skill performance. Am College Sports Med 2007; p.1969-1970

13. Khanna GL, Manna L. Supplementary effect of carbohydrate-electrolyte drink on sports performance, lactate removal \& cardiovascular response of athletes. Indian J Med Res 2005; 121(5):665-9.

14. Rollo I, Clyde W. The influence of fluid solution before and during a 1-hr running performance test. Int J Sport Nutr and Exe Metab 2009; 19(6):645658. p. 645.

15. Guerra I, Chaves R, Barros T, Tirapegui J. The influence of fluid ingestion on performance of soccer players during a match. J Sports Sci Med 2004; 3, 198-202. p.198-9.

16. Clarke ND, Drust B, MacLaren DP. Strategies for hydration and energy provision during soccerspecific exercise. Int J Sport Nutr and Exe Metab 2005; 15, 625-640.

17. Temesi J, Johnson NA, Raymond J, Burdon CA, O'Connor HT. Carbohydrate ingestion during endurance exercise improves performance in adult. J Nutr 2011. p1.

18. Bogdanov S, Jurendic T, Sieber R, Gallmann P. Honey for nutrition and health: a Review. Am J College Nutr 2008; 27: 677-689. p1. p4-9. p15.

19. National Honey Board. Carbohydrate and the sweetness of honey. [serial online] 2010 [dikutip 2012 Okt 27]. [4 halaman]. Tersedia URL: http://faculty.ksu.edu.sa

20. Mayhew I. Ergogenic efficacy of honey based sports drink during a simulation 56 mile cycling time trial. [dissertation]. University of Chester; 2007.

21. Guyton C, Hall JE. Buku ajar fisiologi kedokteran. edisi 11. Penerbit buku kedokteran: 2007; p11111123

22. Steiger VM, Williams CA. Carbohydrate intake considerations for young athletes. J Sport Sci Med 2007; 6, 343-352.

23. Moghaddam Elham, Vogt JA, Wolever Thomas. The effects of fat and protein on glycemic responses in nondiabetic humans vary with waist circumference, fasting plasma insulin, and dietary fiber intake. J. Nutr. 136: 2506-2511, 2006. p1,4

24. Meludu SC, Asomugha L, Dioka EC, Osuji C, Agbasi AC, Ifeanyichukwu M, et al. Exercise performance in relation to glucose drink and their effect on some biochemical parameters. Nigerian J Physiol Sci 2005; 20(1-2): 43-47.

25. American Diabetic Association. Consensus statement: postprandial blood glucose. Diabetes care 2001; 24: 4. p 775.

26. Dorfman L. Nutrition for exercise and sports performance. In: Mahan LK, Sylvia Escott-Stump. Krause's food, nutrition, \& diet therapy. 11th ed. Philadelphia: Saunders; 2008.p.590-602.

27. Ehab SM, Mahamed NS. Effect of a nutrition compound (honey and water) on blood glucose, body temperature and some physiological variables in wrestlers. World Journal of Sport Sciences 2010; 3 (S): 930-935. p. 930-1

28. Wendy J, O’brien, David S. Fructose-maltodextrin ratio in a carbohydrate-electrolyte solution differentially affects exogenous carbohydrate oxidation rate, gut comfort, and performance. Am J Physiol Gastrointest Liver Physiol 2010; 300:181-189.

29. Abbey EL, Rankin JW. Effect of ingesting a honey-sweetened beverage on soccer performance and exercise-induced cytokine response. Int $\mathbf{J}$ Sport Nutr Exe Metab 2009; 19(6):659-72. 